\title{
Research on the Cultivation of Innovative and Entrepreneurial Ability of Information Management and Information System Major
}

\author{
Biyu Qin \\ School of Economics and management \\ Beijing Institute of Graphic Communication \\ Beijing, China \\ xqlwtg@163.com
}

\begin{abstract}
The aim of this study is to strengthen the cultivation of students' independent innovation and practice ability in information management and information system major, improves students' comprehensive quality and promote the development of this major. This paper analyzed the current situation and existing problems of innovation and entrepreneurship education of information management and information system major by comparative research method. In this study, we put forward the orientation of training objectives and the quality structure of personnel training for the major of information management and information system, and explore five ways to integrate the major of information management and information system with the innovation and entrepreneurship education.
\end{abstract}

Keywords-Innovation and entrepreneurship education; Information management professional education; Tutorial system; Scientific research project driven

\section{INTRODUCTION}

In order to deepen the reform of entrepreneurship education in higher education, under the background of "mass entrepreneurship and mass innovation", how to seize the opportunity for information management and information system specialty, relying on the construction of trust management specialty and teachers' scientific research projects to implement the integration of innovation and entrepreneurship education has become an urgent problem for the current trust management specialty. It is of great significance to clarify the training objectives of the major of information management and to strengthen the integration of innovation and entrepreneurship education with the major for enhancing students' entrepreneurial awareness, improving students' entrepreneurial employment skills, and enhancing the employment rate. The quality of the whole society in information system application, information management, information analysis, information acquisition and other aspects has been generally improved, which has brought severe challenges to the students majoring in information management: students need to have more professional, faster information acquisition and information analysis capabilities, with more efficient and targeted information management and

The project is funded by the Beijing Institute of Graphic Communication education reform project. information development capabilities, comprehensive knowledge of more systematic enterprise management, information management and information system development, and the ability to integrate this knowledge.

\section{CURRENT SITUATION OF INNOVATION AND} ENTREPRENEURSHIP EDUCATION IN INFORMATION MANAGEMENT AND INFORMATION SYSTEM MAJOR

\section{A. Problems arising from existing knowledge structures}

Information management and information system expertise involves three major categories of economic management, information management and computer. If you can't combine the knowledge of three different subject areas, the course of information management and information system becomes a "big platter". This is also a common problem faced by some information management and information system majors in China. Many information management and information system students feel that they are learning everything, but they don't learn anything, they can't learn, and they don't have core competitiveness when they are employed. Due to the large span between different types of courses and courses in information management and information system, students can't combine the logic of the courses well, and the teachers are not able to combine the courses with other courses. As a result of teaching, students' understanding of information management and information system professional knowledge is not thorough, and it is impossible to absorb innovation on the basis of existing knowledge, and even produce the idea of "learning useless" [1]

\section{B. The Curriculum System Is Not Perfect}

Since innovation and entrepreneurship education and information management and information system professional education are still in their infancy in China, although many institutions have set up dual-creation courses, they have not yet established a comprehensive and systematic curriculum system. The innovation and entrepreneurship courses are mainly elective. Courses, especially the core courses of information management and information systems, overlap with the innovation and entrepreneurship courses. The 
professional courses and innovation and entrepreneurship courses are separated, lacking organic integration.

\section{The Innovative Entrepreneurial Faculty Is Weak}

The innovative entrepreneurship education is practical, requiring teachers to have good professional knowledge, but also to have the awareness and experience of innovation and entrepreneurship $^{[2]}$. However, because China's enterprises have achieved a slow start in information management, they are not enough to pay attention to Chengdu. Teachers lack relevant experience in corporate work. Practical guidance on students' innovation and entrepreneurship can result in fewer teachers with both, which has become the soft underbelly of innovation and entrepreneurship education.

\section{The Assessment and Evaluation Methods Are Backward}

In the evaluation of students in the school, no matter which major is the course, the basic examination method is basically adopted. This method can not satisfy the evaluation of students' innovation and entrepreneurship ability and level, which is not conducive to promoting the cultivation and improvement of students' comprehensive quality ${ }^{[3]}$.

\section{THE QUALITY STRUCTURE OF INFORMATION MANAGEMENT AND INFORMATION SYSTEM PROFESSIONAL TALENT NEEDS INNOVATION AND ENTREPRENEURSHIP}

\section{A. The Training Objectives of Innovation and Entrepreneur Talents in Information Management and Information System}

According to the needs of social development, combined with the training objectives of disciplines and the needs of students' physical and mental development, on the basis of the cultivation of basic quality and professional quality, the core of improving the social responsibility, innovation, entrepreneurial awareness and entrepreneurial ability of the educated people have the spirit, ethics, knowledge and ability related to innovation and entrepreneurship and have strong self-control, self-management and self-improvement. They can be themselves in the field of social practice and understanding of information resource management and information system development. Creative work to know the world or transform the world ${ }^{[4]}$.

Innovative entrepreneurship education is not a skill training activity that is isolated from professional education. Its integration with professional education should be systematic and comprehensive, from the integration of professional education objectives, educational concepts, educational processes, and education guarantees. The innovation and entrepreneurship education of information management and information system is conducive to promoting the frontier knowledge and achievements of professional education dynamics in the fields of information technology and information resource management and utilization. Based on the curriculum system of innovation and entrepreneurship training, the key is how to realize the integration of professional education and innovation and entrepreneurship education. The biggest difficulty of the corresponding reform is how to realize the transformation and transition from the traditional professional education curriculum system to the innovation and entrepreneurship education curriculum system.

\section{B. Analysis on the Quality Structure of the Professionals of Information Management Needed for Innovation}

In the context of big data era and mobile internet, analyze the research on the capacity demand of information management and information system professionals in the employment market and the status of information management and information system professional innovation and entrepreneurship education, timely adjust the information management and information system professional training program, and reposition Information management and information system professionals training objectives, construct a reasonable subject knowledge structure, strengthen professional ability and practical ability training, cultivate students' thinking of innovation and entrepreneurship, and enhance students' ability to practice innovation and entrepreneurship.

The major adjustments to the knowledge structure module are mainly in the professional courses. Some professional courses will be added or replaced according to the development of databases and Internet technologies and the upgrading of development tools. The professional courses, practical training, and innovative entrepreneurship training required for the training of innovative and entrepreneurial talents in information management and information systems are as follows ${ }^{[5]}$.

Information Management and Information Systems Professional Courses: Database Technology and Applications, Network Development Technology and Applications, Information System Analysis and Design, Digital Media Technology and Content Management, Data Science Introduction, Business Data Analysis, APP Design and Production, Big Data Technology and Applications, cloud computing foundation, multimedia design and production, supply chain management, enterprise resource planning, IT project management, publishing enterprise management, ASP.net programming, information system development new technology, Oracle database technology and applications.

Practical teaching includes web design and production, mobile information system development and application, multimedia design and production, ERP sand table simulation, APP design and production, business data analysis and mining, information system design and development.

Innovative entrepreneurship training includes WeChat small program development training, information system application development comprehensive ability training, innovation and entrepreneurship project selection guide and training. 


\section{THE WAY TO INTEGRATE INNOVATION AND ENTREPRENEURSHIP EDUCATION WITH INFORMATION MANAGEMENT AND INFORMATION SYSTEM PROFESSIONAL EDUCATION}

\section{A. Clarify the Goal of Training Professionals in Information} Management and Information Systems, and Build a

TalentTraining System that Integrates with Innovation and Entrepreneurship

The information management and information system specialty is a multidisciplinary major involving computer, management science, economics, etc. The orientation of talent training should be based on the combination of information technology and economic management talents. Combining the training requirements of this major at home and abroad, I believe that the goal of talent training in information management and information systems is to cultivate innovative compound talents that can meet the needs of intelligent economy, intelligent management and intelligent business $^{[6]}$. On the basis of clarifying this goal, the innovation and entrepreneurship education is carried out in the process of professional education, quality education and practical education, forming a four-in-one talent training system of theoretical teaching, practical teaching, quality and innovation and entrepreneurship education, and scientific and technological innovation. Incorporate the spirit of innovation, entrepreneurial awareness and entrepreneurial ability from the talent training program, teaching content, teaching methods, scientific and technological activities into the talent training system.

\section{B. Construct a Reasonable Subject Knowledge Structure and Establish a Curriculum System that Infiltrates Innovation and Entrepreneurship Education}

In order to achieve the training of innovative and entrepreneurial composite information management and information system professionals, the curriculum system is particularly important. How to combine economics, management, computer technology and innovation and entrepreneurship education courses, how to scientifically and reasonably add "research methods", "discipline frontiers", and "innovation" in the course of academic credits "Compulsory entrepreneurship" and "employment entrepreneurship guidance" and other compulsory courses and elective courses, the establishment of an organic and integrated information management and information system professional curriculum system, has become a problem that must be solved in dual education. Compared with other majors, the integration of information management and information systems professional courses and innovative entrepreneurship education courses has great advantages. Courses such as IT strategy, business intelligence, and mobile platform development technology can be appropriately added, so that the organic combination of professional knowledge and innovation and entrepreneurial knowledge can be realized.

\section{Reform the Traditional Education Mode and Cultivate Students' Awareness and Spirit of Innovation and Entrepreneurship}

The experienced teachers adopt scientific and effective teaching methods, so that the ability training can be carried out throughout the classroom teaching. The professional quality, innovative spirit and entrepreneurial skills of the students can be perfectly combined to achieve the ultimate talent training goal. First of all, teachers should adopt heuristic, open and inquiry-based teaching in the teaching, taking students as the main body, encouraging and guiding students to learn independently, developing students' individuality and specialty, and activating students' creative potential and innovative initiative. Students master the strategy of innovative thinking, making their thinking flexible, so as to cultivate students' sensitivity to new knowledge and improve students' ability to discover, analyze and solve problems. Secondly, teachers should closely combine professional knowledge and practice, cultivate students' practical ability, improve students' practical operation skills and ability to solve practical problems, and prepare students for entrepreneurship. Finally, teachers should take the initiative to improve their knowledge and introduce new technologies and new ideas such as big data, cloud computing, Internet of Things, Maker, O2O and Internet+ into the curriculum, inspiring students' imagination and creativity, and guiding students to enhance innovation. Consciousness and entrepreneurship, with knowledge, wisdom and courage to create a career that can play the role of the individual ${ }^{[7]}$.

\section{Strengthen the Construction of Professional Teaching System for Information Management and Information System, and Enhance Students' Ability of Innovation and Entrepreneurship}

The foundation of innovation and entrepreneurship education is practice. In the cultivation of students' innovative and entrepreneurial ability, the laboratory is the base, which is the cradle of innovation spirit and innovation ability cultivation. Students learn to discover problems, analyze problems, and use the accumulated theoretical and practical knowledge to solve problems, so as to have the purpose of innovation, innovation, and innovation, to achieve new goals, propose new methods, and introduce new ideas. In order to achieve the above objectives, better play the role of practical teaching in the cultivation of innovative and entrepreneurial talents, and build a perfect practical teaching system that integrates with innovation and entrepreneurship education, including classroom experiment teaching, enterprise internship training, social practice, technological innovation, Graduation design and graduation internships, and actively encourage and support students to participate in various professional and professional certification. Create a strong atmosphere for scientific and technological innovation for students, and participate in competitions such as the "UF Cup" sand table simulation business competition to enhance students' sense of innovation, exercise and improve their observation, thinking, imagination and hands-on ability. 


\section{E. Tutor System Driven by Scientific Research Projects}

Our school's information management and information system professional pilot program is to let students choose their tutors based on their interests and the research direction of professional teachers, mainly to do some auxiliary work for the tutor, analyze and organize the materials, and simply participate in the teacher's research projects. The implementation of the original tutor system was not particularly good. After several years of exploration, it is mainly driven by the research projects of teachers. Teachers have proposed some small topics suitable for students according to their own research projects. Student groups (can be organized across professional groups) In the form of innovation and entrepreneurship, the teachers identify the innovative and entrepreneurial declaration topics, provide research hotspots and frontiers, and the students consult relevant literature ${ }^{[3]}$. The teachers guide students to some research methods, form the framework of research projects, and determine the topics of innovation and entrepreneurship.

\section{CONCLUSION}

Cultivating innovative and entrepreneurial talents is the fundamental task of higher education institutions and the current strategic direction of higher education in China. Professional education is the foundation of entrepreneurship education. One-sided emphasis on innovation and entrepreneurship education, neglect and weaken professional education, is to seek the end, the edge of the wood, the innovation and entrepreneurship education will become a passive water, no roots, and ultimately can not achieve our desired goals. To clarify the orientation of information management and information system professional training, we can better integrate innovation and entrepreneurship education into the whole process of professional education, and realize the cultivation of innovative composite information management and information system professionals.

\section{REFERENCES}

[1] Li Yang, Xiaojun Guo. Research on the Cultivation of Professional Talents' Innovative Ability in Information Management and Information System, Journal of Modern Information, vol.32, PP. 139-141, June 2012.

[2] Yuanfang Dong, Yan Li. Research on the training mode of innovation ability of students majoring in credit management, Journal of Changchun University of Science and Technology (Social Science Edition),vol.28,pp.144-149, July 2015.

[3] Ying Liang, Jingguo Dai. Research on the Innovation and Entrepreneurship Talent Cultivation Model of Information Management and Information System, Journal of Shaoguan University (Natural Science), vol.36, pp.73-77, April 2015.

[4] Liangcheng Yang. Research on the curriculum system of information management specialty based on the cultivation of innovative and entrepreneurial talents. Theory Research, pp:185-188, January 2015.

[5] Qingping Ni. Design of Practice Course System for Training Comprehensive Ability of Information System Application and Development. China Management Informationization, vol.13,pp:118119, March 2010.

[6] Weichao Li. Entrepreneurship education should be integrated into professional education, Guangming Daily,23 June 2015.

[7] Linnan Huang, Zengfang Han. Reflections on the Embedding of Professional Education in Innovation and Entrepreneurship Education, Education and Occupation, pp.87-88, May 2012. 